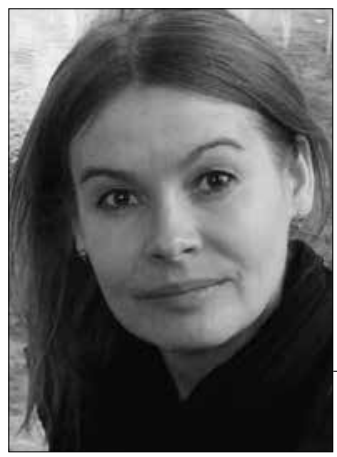

https://doi.org/10.24101/logos.2021.55

Gauta 20210901

LINA VIDAUSKYTE்

Generolo Jono Žemaičio Lietuvos karo akademija, Lietuva

General Jonas Žemaitis Military Academy of Lithuania, Lithuania

\title{
DVASINĖS PRATYBOS, METAFOROLOGIJA IR FILOSOFINIS KONSULTAVIMAS
}

\author{
Spiritual Exercises, Metaphorology and Philosophical Counseling
}

SUMMARY

The aim of this article is to analyze the possibilities of applying metaphorology in philosophical counseling, based on the philosophical insights of Hans Blumenberg and Pierre Hadot. Metaphorology, or non-conceptual theory, is a direction marked by Blumenberg. Its possibility of is completely unexplored in philosophical counseling. Hadot is primarily known for his exceptionally original interpretation of Ancient Philosophy and his entrenched conception of spiritual exercises. The concepts are difficult to apply in a specific existential situation, but metaphors focus on human imagery and are a kind of gestalt of reality. Spiritual exercises perceived as a philosophical way of life help to concretize the theory and to apply it in life situations.

\section{SANTRAUKA}

Šiame straipsnyje aptariamos metaforologijos taikymo galimybės filosofinėje praktikoje remiantis Hanso Blumenbergo ir Pierre'o Hadot filosofinėmis įžvalgomis. Metaforologija, arba ne-konceptualumo teorija, yra Blumenbergo nužymėta kryptis, kurios galimybės filosofiniame konsultavime yra visiškai netyrinètos. Hadot pirmiausia yra žinomas dèl savo išskirtinai originalios Antikos filosofijos traktuotès ir įtvirtintos dvasinių pratybų sampratos. Kitaip nei sąvokos, metaforos orientuotos į žmogaus vaizduotę ir yra savotiški tikrovès geštaltai, vaizdiniai. Dvasinės pratybos, suvoktos kaip filosofinis gyvenimo būdas, padeda sukonkretinti teoriją, ją taikyti gyvenimiškose situacijose.

\section{IVADAS}

Nors filosofinis konsultavimas yra tinės filosofijos šaka, tačiau per palyginpalyginti nauja, vos praeito amžiaus de- ti trumpą laiką čia jau yra pasiekta nevintajame dešimtmetyje atsiradusi prak- blogų rezultatų išbandant įvairių filoso-

RAKTAŽODŽlAI: metaforologija, dvasinès pratybos, filosofinis konsultavimas, Blumenbergas, Hadot.

KEY WORDS: metaphorology, spiritual exercises, philosophical counseling, Blumenberg, Hadot. 
fijos temų bei idëjų taikymo galimybes, kai tenka konsultuoti asmenis, kurie išgyvena egzistencines problemas bei ieško gyvenimo prasmès. Filosofinis konsultavimas yra artimas egzistencinei psichoterapijai. Jo pamatą sudaro istoriškai susiformavusi filosofinès kalbos tradicija ir išmintis, traktuojama daugiau kaip gyvenimo būdas, o ne kaip grynoji teorija. Svarstant apie filosofinio kon- sultavimo kalbos specifikos klausimą ypatingą demesi verta atkreipti $\mathfrak{i}$ vieno itakingiausių XX a. antros pusès filosofuc Hanso Blumenbergo (1920-1996) inicijuotą metaforologijos projektą. Tuo tarpu filosofijos kaip išminties požiūriu itin produktyvi gali būti atožvalga i̇ Pierre'o Hadot (1922-2010) atgaivintą antikinę filosofijos kaip gyvenimo būdo ir dvasinių pratybų sampratą.

\section{PIERRE'AS HADOT: FILOSOFIJA KAIP DVASINĖS PRATYBOS}

Hadot atlikti senovès graikų filosofijos tyrinejjimai filosofinio konsultavimo požiūriu neabejotinai svarbūs pirmiausia tuo, kad jie padeda îveikti ìsisenejjusi požiūrị, esą filosofija yra teorinè disciplina, plètojanti teorini diskursa, kuris turi eksplikuoti ir paaiškinti bendriausius tikrovės kaip visumos principus. Iš pirmo žvilgsnio gali pasirodyti, kad toks požiūris yra visiškai pagrịstas. Jis remiasi akivaizdybe, jog pats mąstymas yra diskursyvus, t. y. i konkretybę visuomet žvelgia pro abstrakcijos prizmę ir tuo būdu kiekvieną detalę padeda suvokti visumos kaip vienovès kontekste. Šiuo požiūriu ir žmogaus gyvenimui reikšmingų dalykų filosofinis apmąstymas yra ne kas kita, kaip tik diskursyvus tu dalykų išvedimas iš bendruju principų. Tada bet koks žmogaus ,gyvenimiškas apsisprendimas“ laikomas „teisingu“ ar „pagrịstu“, jei jis gali būti logiškai samprotaujant išvestas iš vienokių ar kitokių visuotinių akivaizdybių. Filosofui nerūpi, ar tas pasirinkimas bus faktiškai igyvendintas gyvenime, ar liks vien izsivaizduojamas bei konstruojamas „grynajame mąstyme".
Hadot bando parodyti, kad tokia filosofijos samprata neturi nieko bendro su tuo, kaip filosofiją suprato senovès graikai. Savo puikioje knygoje Antikos filosofija. Kas tai? jis rašo: „Savo knygoje ketinu parodyti tą gilų skirtumą tarp Antikos laiku filosofijos sampratos ir to, kaip ji suprantama mūsų dienomis, bent jau remiantis tuo vaizdu, kuris paprastai pateikiamas studentams iš akademinès būtinybès" (Hadot 2005: 10).

Tyrinėdamas senovès filosofuc tekstus bei liudijimus apie ju gyvenima, Hadot itikinamai parodè, kad senovès graikams filosofija nebuvo vien teorinis diskursas, tekstų rašymas ar juo labiau - vien akademinè karjera. Antikoje filosofu pirmiausia buvo vadinamas tik toks asmuo, kuris gyvena filosofiškai. Filosofinių tekstų rašymas čia buvo visiškai nebūtinas dalykas. Hadot pabrèžia:

bent jau nuo Sokrato laikų galimybė rinktis specifini gyvenimo būdą nèra nustumta i paskutinę filosofinès veiklos vieta, it koks papildomas priedas; priešingai, ji atsiduria pačioje pradžioje dèl sudètingos sąveikos tarp kritinès reakcijos kitu gyvenimiškų nuostatų atžvilgiu, kaip visa 
apimantis konkretaus gyvenimo būdo ir pasaulèžiūros vaizdas ir pats laisvas apsisprendimas. <...> Tad filosofinis diskursas prasideda nuo gyvenimo būdo, nuo egzistencinio pasirinkimo, o ne atvirkščiai (Hadot 2005: 11).

Teorinis diskursas senovès filosofams buvo reikšmingas tiek, kiek filosofinio gyvenimo būdo egzistencinis pasirinkimas suponuoja tam tikrą pasaulèvaizdi. Kaip tik ši pasaulèvaizdi filosofinis diskursas turi išskleisti bei racionaliai pagristi. Todèl, teigia Hadot, "filosofini diskursą reikia suprasti iš specifinès gyvenimo būdo perspektyvos, vienu metu kaip priemonę ir kaip išraiškos būdą. Iš to sektų, kad filosofija visų pirmiausia yra gyvenimo būdas, bet glaudžiai susijęs su filosofiniu diskursu" (Hadot 2005: 12). Hadot pabrèžia, kad senovès graikų mąstymas buvo pirmiausia intuityvus, kad izžvalga čia visuomet yra pirminè diskurso atžvilgiu. Jis aiškina:

Filosofinio gyvenimo esmè - egzistencinis konkretaus gyvenimo būdo pasirinkimas, tam tikrų būsenų, vidinių nuostatu patirtis; jos filosofinis diskursas nepajègia apimti. Akivaizdžiausiai šią situaciją atskleidžia platoniška meilès patirtis, gal net ir Aristotelio paprastujų substancijų intuicija. Pati ryškiausia - Plotino vienijanti patirtis, kurios kaip tokios visiškai neimanoma išreikšti žodžiais, nes kalbantysis apie ją kalba jau pasibaigus patirčiai, būdamas nebe tame pačiame psichiniame lygmenyje. Tačiau tą pati galime sakyti ir apie epikūrininkų, stoikų, kinikų patirtis (Hadot 2005: 205).

Tačiau ne mažiau svarbu yra tai, kad pati „filosofini diskursą galima apibrèžti kaip dvasines pratybas, skirtas sužadinti radikalų egzistencini pokytį" (Hadot 2005: 208).

\section{HANSO BLUMENBERGO METAFOROLOGIJA}

Norint geriau suprasti Hadot eksplikuotos gyvenimo būdo ir filosofinio diskurso sąveikos dialektikos reikšmę filosofiniam konsultavimui, pravartu atidžiau pažvelgti i paties diskurso struktūrą. Atrodytu, kad tai, ką randame analizuodami šią struktūra, yra ne kas kita, kaip tik sąvokos. Bet jei taip, tai lieka nesuprantama, kaip toks grynai „,sąvokinis“, t. y. neišvengiamai abstraktus, diskursas gali daryti poveikį visiškai konkrečiam filosofinio gyvenimo būdo pasirinkimui. Ieškant atsakymo ị šį klausimą, svarbią nuorodą galime aptikti Blumenbergo inicijuotame metaforologijos projekte.

Šis projektas kartais vadinamas ",metaforos hermeneutika“, tačiau "herme- neutikos" sąvoka šiuo atveju gali klaidinti, nes kelia asociacijas su H.-G. Gadamerio ar P. Ricoeuro koncepcijomis, nuo kurių Blumenbergas atsiribojo. Metaforologijos konceptualią aši sudaro pastanga parodyti, kad metaforos darè daug didesnę ittaką Europos intelektualinei kultūrai nei sąvokos ar konceptualinès schemos. Blumenbergas bando parodyti, kad metaforos nèra vien aiškaus, konceptualaus filosofinio kalbèjimo puošmena ar priedas, kaip manè jau Aristotelis. Anot Blumenbergo, metaforos yra visiškai savarankiška kalbèjimo forma, kuri filosofineje kalboje atlieka nepaprastai svarbu vaidmenį. Jos yra vaizdai, vaizdinès konstantos, kuriomis naudojasi filo- 
sofai siekdami padèti žmogui susiorientuoti jo gyvenamajame pasaulyje (plg. Blumenberg 2013: 11-17). Atsižvelgiant jau vien i tokią metaforų funkcija, darosi aišku, kad metaforologija gali būti nepaprastai svarbi filosofiniam konsultavimui, kurio tikslas juk taip pat yra padèti dèl prasmès trūkumo kenčiančiam žmogui aptikti pamatinius gyvenimo orientyrus.

Metaforologijos pagrindinè ideja buvo suformuluota knygoje Paradigmen zu einer Metaphorologie (2013) ir išplètota vėlesniuose darbuose, kuriuose, patikslindamas savo plètojamos koncepcijos pobūdi, Blumenbergas metaforologiją vadina jau „nesąvokiškumo teorija“ (Theorie der Unbegrifflichkeit). Ši terminologini pakeitimą jis aiškina taip: „, $<\ldots>$ metaforologijos funkcija nepakito, bet jos referentas dabar yra ne metafora, o ypatingi nekonceptualizuojamumo atvejai“ (Blumenberg 1979: 83). Trumpai tariant, Blumenbergą domino tokios prasmès raiškos formos, kurios negali būti iki galo konceptualizuotos - specialaus tipo metaforos, kurias jis vadina „absoliučiomis metaforomis". „Absoliučios metaforos aptikimas", rašo Blumenbergas, ",turètų padèti mums iš naujo apmąstyti santyki tarp fantazijos ir logoso - būtent ta prasme, kad fantazijos sritis būtų traktuojama ne kaip vien transformacijos i sąvokas substratas <...>, o kaip katalizacijos sfera, kurią sąvokų pasaulis nuolatos vartoja save praturtindamas, bet sykiu tos srities nepakeičia ir nesuvartoja" (Blumenberg 2013: 14).

Absoliučios metaforos yra tie nesąvokiniai (ar iki-sąvokiniai) filosofinio diskurso elementai, kurie grindžia sąvokini mąstymą ir apibrèžia jo horizontą.
Tų metaforų vadinimas absoliučiomis metaforomis reiškia tik tiek, kad jos pasirodo kaip atsparios terminologijos pretenzijoms ir kad neįmanoma jas ištirpdyti konceptualizacijoje, nors tai nereiškia, kad tam tikros metaforos neįmanoma pakeisti ar reprezentuoti kita metafora ar pataisyti kokia nors tikslesne (Blumenberg 2013: 13).

Remdamasis tokia absoliučių metaforų samprata, Blumenbergas savo projekto esmę nusako taip: „metaforologija bando prisikasti iki mąstymo substruktūros, iki jo giliausio pamato, jo sisteminančią kristalizaciją maitinančio tirpalo (Blumenberg 2013: 13).

Štai keletas Blumenbergo siūlomų absoliučių metaforų pavyzdžių: „šviesa", „nuoga tiesa“, „pasaulio knyga“, „kelionè", "plaukiojimas jūromis", ,laivo katastrofa su žiūrovu (Schiffbruch mit Zuschauer ${ }^{\text {“1 }}$. Blumenbergas pabrèžia, kad nuo to, kokia absoliuti metafora kurioje nors epochoje dominuoja, priklauso tiesos samprata bei žmogaus santykis su tiesa, taip pat žmogaus vietos pasaulyje supratimas. Keičiantis tokiems pamatiniams vaizdiniams, keičiasi mąstymo paradigma ir prasideda nauja epocha. Tačiau bet koks bandymas tą pasikeitimą aprašyti sąvokomis yra anachronizmas, tačiau tai nereiškia, kad ankstesnių epochų mąstysena bei jausena mums visiškai nepasiekiama. Tai, ko nepajègia padaryti sąvokos, gali pateikti metaforos.

Tad metaforologiją galima traktuoti kaip savotišką nesąvokiškumo archeologiją ar paleontologiją, tyrinejjančią žmogaus teorinio intereso archajini sluoksnį. Ši disciplina siekia įveikti „,karteziškają logizavimo teleologija, traktuo- 
jančią metaforas kaip 'rudimentus'“ (Blumenberg 2013: 10) ir tuo būdu grąžinti į istorijos horizontą savo vertę neva praradusiu metaforu "fosilijas". Jei pavyksta tai padaryti, absoliučioje metaforoje gali atgyti nekonceptualizuojama patirtis, savitu būdu atverianti tikrovę kaip išmintis, kurią žmogus (neretai pats to iki galo nesuvokdamas) aktualizuoja savo gyvenimu. Tai, kad kitaip nei filosofinè sąvoka, kuri visuomet yra labai apibendrinamojo pobūdžio, metafora visuomet yra konkreti, ji gali pereiti $\mathfrak{i}$ kitą konteksta, o kaip tik tai ir leidžia ją lengviau taikyti gyvenimiškose situacijose nei sąvoką.

Galima sakyti, kad visą Blumenbergo mąstymą organizuojanti tema yra tai, ką jis pats įvardina kaip "tikrovès absoliutizmą (Absolutismus der Wirklichkeit)“. Šia sąvoka Blumenbergas žymi tą aplinkybę, $\mathrm{kad}$ „žmogus nedisponuoja savo egzistencijos sąlygomis" (Blumenberg 2014: 9). Tai, kad tikrovè nepavaldi ne tik žmogaus pastangoms ją pakeisti, bet ir suprasti, kelia žmogui baimę ir neviltị. Maža to, pats supratimas čia tampa problema.

„Panašu“, rašo Bumenbergas, „kad teiginys: mes nežinome, ka turime omenyje, kai vartojame žodị 'prasmè', reikalauja iš mūsų nemenkos drąsos. <...> Sigmundas Freudas buvo teisus, kai pasakè, kad tie, kurie klausia apie gyvenimo prasmę, yra ligoniai. Vadinasi, užuot atsakius i ju klausima, juos reikia pagydyti; o jei ne pagydyti, tai paguosti“ (Blumenberg 1987: 59). „Paguoda“, apie kurią čia kalba Blumenbergas, yra vienintelis dalykas, kuri žmogus gali gauti bandydamas iveikti „tikrovès absoliutizmo“ keliamos beprasmybės neviltị. Tačiau tai toli gražu nèra toks menkniekis, kaip gali pasirodyti. Ko gero, čia būtu pravartu prisiminti Nietzsche's teigini, kad „pasaulio egzistavimas gali būti pateisinamas tik kaip estetinis fenomenas" (Nietzsche 1997: 25). Metaforologija gyvenimo prasmès paieškas perkelia iš pažinimo ar moralès srities ị sritị, kurią galima identifikuoti kaip estetikos sriti.

\section{GOETHE'S MAJEUTIKA}

Vieną iš tokios „metaforologinès paguodos" pavyzdžiu (beje, puikiai tinkančiu tyrinëjant metaforologijos pritaikymo filosofiniame konsultavime galimybes) Blumenbergas pateikia esė kiek neiprastu pavadinimu Schon wieder Appetit zu Feigen (Blumenberg 1987: 25-35). Šioje esė jis analizuoja Goethe's laišką bičiuliui Karlui Friedrichui Zelteriui, išgyvenusiam skaudžią netektį - sūnaus savižudybę. Blumenbergas atkreipia dèmesị i tai, kad savo bičiuli Goethe guodžia labai neiprastu būdu: užuot, kaip tai paprastai daroma, bandęs postringauti apie tai, kad „nieko čia nepadarysi“, ,toks jau yra tas gyvenimas", "reikia būti tvirtam“ ar pan., jis prisimena savo paties jaunystès išgyvenimus, kurie ikvėpe ji parašyti Jaunojo Verterio kančias ir baigia šią laiško dalì mįslinga fraze: ,jūra ir vèl nori fi$\mathrm{gu}^{\prime \prime}$. Gana išsamiai aptaręs gausybę su figu ìvaizdžiu susijusių ir Goethe'i neabejotinai žinomų literatūrinių asociacijų, Blumenbergas atkreipia demesi i tai, kad Zelteris, kuris buvo tik neturintis klasikinio išsilavinimo savamokslis muzikas, 
viso to daugiasluoksnio prasmių raizginio žinoti negalejo. Tad kokia gi čia paguoda tèvui, kuris kankinasi, nes nepajègia suvokti sūnaus savižudybès prasmès. Visiškai kitokia yra Goethe's situacija. „Kaip Verterio autorius, jis šitai pažista“, rašo Blumenbergas, "nes pats tąsyk vos paspruko nuo mirties bangų. $<\ldots>$ Bet ne "toks jau yra tas gyvenimas" nustato guodžianti ryši ir bendrystę, kuriuos galima iš viso to išgauti, ir kuriais galima remtis. Greičiau, rašo Goethe, šitaip savo istoriją pasakoja visi tie, kurie patyrè vienatvę ir pavoju, nes tik tie, kam pavyksta pasprukti, gali pasakoti istorijas. Būtent čia glūdi nebendramatiškumas su tylejjimu to, kuris jau nebegali atskleisti savo poelgio prasmès, poelgio, kurio mịsle kankina Zelterị “ (Blumenberg 1987: 25). Gali būti, kad Goethe sąmoningai guodžia bičiuli mitologinių ir egzistencinių prasmių prisodrinta ${ }^{2}$, bet guodžiamajam nesuprantama metafora, suvokdamas, kad tikra paguoda gali rastis iš to, jog viena nesuprantamybė atsvers kitą nesuprantamybę ir viena paslaptis pasitiks kitą paslapti (Blumenberg 1987: 26). Tokia nesuprantamybių ar paslapčių pusiausvyra atveria žmogui prieiga prie dabarties akimirkos, o tikroji paguoda imanoma tik tuo mastu, kuriuo paguodos žodžiai padeda guodžiamajam maksimaliai tą akimirką išgyventi.

Kaip tik apie tai savo paskutineje knygoje N'oublie pas de vivre. Goethe et la tradition des exercices spirituels (2008) rašo Hadot. Kai kuriems skaitytojams galejo pasirodyti netikèta, kad Antikos filosofijos žinovas atsigręžè i Goethe's kūryba, tačiau atidžiai skaitant Hadot ankstesnes publikacijas nesunku pastebèti, kad prancūzų filosofo ir vokiečiu poeto pažiūros daugeliu atžvilgių yra labai artimos. Paskutineje savo knygoje Hadot sutelkia dèmesi i dvi Goethe's kūryboje aptinkamas ir su filosofijos kaip „dvasinių pratybų" tema tiesiogiai susijusias metaforas: „žvilgsnis iš aukštai“" (tai kartu ir skrydžio metafora) ir "laimè tik dabartyje“. Pirmojoje metaforoje Hadot nesunkiai atpažista nuorodą i Epikūro ir stoiku filosofinèse mokyklose taikytą meditacijos metodiką. Aptikęs šią metaforą Goethe's poetiniuose tekstuose, Hadot parodo, kad jos funkcija yra panaši i ta kurią savo pratybose naudojo senovės filosofai. Stoikai, kurių filosofiją Goethe neblogai išmanè ir aukštai vertino, vartodavo tam tikrus posakius, kurie, jei žmogus juos teisingai issisąmonina, pakylëja ji virš gyvenimo rutinos beprasmybès ir leidžia patirti prasmę. Žvilgsnio iš aukštai (arba skrydžio) metafora yra nuoroda i atsiribojimą nuo sudètingos situacijos, reikalingą tam, kad galima būtų aiškiau suvokti painius labirintus, kuriuose konkreti egzistencija jaučiasi pasiklydusi ir pasimetusi. Tačiau tai nèra toks abstrahavimasis nuo konkretybės, koki teikia mums abstrakčios sąvokos. Žvilgsnio iš aukštai metafora leidžia tą konkretybę suvokti kartu su jos platesniu horizontu. Tačiau, kad tai taptų imanoma, reikalingas atkaklus darbas, kuri galima, be kita ko, gretinti ir su poetinio teksto mokymusi atmintinai. Čia galima prisiminti ir George'o Steinerio svarbią ižvalga, kai savo knygoje Tikrosios esatys jis rašo: 
Atskiras skaitytojas arba klausytojas, atmintinai išmokdamas eilèrašti arba muzikini pasaža, gali tapti pajaustos prasmès vykdytoju. Išmokti atmintinai - vadinasi, suteikti tekstui arba muzikai įsigyvenantị aiškumą ir gyvybinę jègą. <...> Tai, ką mokame atmintinai, tampa veiksniu mūsų sąmonejje, tapatybès tobulèjimo ir jos gyvybiškos plètotès „katalizatoriumi“ (Steiner 1998: 12-13).

Eksplikuodamas antrąją metaforą („laimè tik dabartyje“), Hadot pateikia Goethe's Fausto II dalies 3-ojo veiksmo vieno epizodo prancūzišką parafrazę. Šiame epizode Faustas ir Helena, pritardami vienas kitam, sako: „Alors l'esprit ne regard ni en avant ni en arrière. Le present seul est notre bonheur" („Dvasia nesižvalgo nei pirmyn, nei atgal. Mūsų laimè yra tik dabartis“) (Hadot, 2008: $15)^{3}$. Hadot atkreipia demesi i tai, kad čia turime reikalą su kalbèjimu įsimylèjèlių, kuriems dabartis yra ne tik tam tikra laiko fazè, bet ir ju buvimas šalia vienas kito, t. y. vienu metu ,aktualumas laike ir artumas erdvèje (actualité temporelle et proximité spatiale)" (Hadot 2008: 23). Būtent tokią dabarties sampratą Hadot aptinka ir 1829 m. Goethe's laiške Zelteriui. Šiame laiške Goethe pažymi, jog jo amžininkai iškreiptai suvokia tai, kas vadinama "dabartimi“ (Gegenwart). Jie mano, kad dabartis yra triviali ir todèl tik praeities nostalgija gali atverti mums gilesnę ir nebanalią tikrovès prasmę. Hadot nurodo, kad "Goethe vartoja žodi Gegenwart, išsaugodamas jo pirminę „prezencijos“ reikšmę apsireiškimo, manifestacijos, „štaibuvimo" (être-là) priešais mus prasme.
Tad šis žodis yra žodžio Dasein, „štaibuvimo" (être-là) sinonimas. Džiaugiamès prezencija (Gegenwart) arba štai-buvimu (Dasein)“ (Hadot 2008: 63). Taip suprantama „dabartis“ yra ne kas kita, kaip aktualiai išgyvenama žmogaus gyvenimo konkretybè.

Tokią dabarties momento patirti Hadot sieja su Goethe's fenomenaliu sugebejjimu išgyventi to momento šventumą taip, kaip jis būdavo išgyvenamas antikoje, sykiu pabrěždamas, kad šiuolaikiniai žmonès beveik nesugeba to išgyventi kaip tik todèl, kad nuolatos pasiduoda arba praeities nostalgijai, arba visas savo viltis sutelkia $i \mathfrak{i}$ ateitį. Kita vertus, būtent tokia dabarties patirtis ir yra pagrindinis filosofinio konsultavimo orientyras ir siekinys. Tad galima sakyti, kad Goethe's "gyvenimo menas" yra filosofinio konsultavimo pagrindinis orientyras. „Kai rašiau šią knygą jausdamas, kad senstu“, prisipažista Hadot, „mane persekiojo memento mori mintis. Tačiau paveiktas Goethe's, supratau memento vivere prasmę ir pagalvojau, kad Goethe's šūkis „nepamiršk gyventi“ gali puikiai reziumuoti mano knygos turini ir tapti jos pavadinimu“ (Hadot 2008: 11). Bet būtent šis šūkis gali būti traktuojamas ir kaip filosofinio konsultavimo pagrindinis orientyras. Šiuo požiūriu pro Blumenbergo metaforologijos ir Hadot atgaivintos antikinès dvasinių pratybų idejjos prizmę skaitomas Goethe pasirodo kaip savotiškas „filosofinis konsultantas“, siūlantis tam tikras performatyviai traktuojamas antikines metaforas ir tuo būdu atliekantis sokratinès majeutikos funkciją. 


\section{IŠVADOS}

Gali atrodyti, kad filosofinis konsultavimas yra naujai atsiradusi filosofijos forma, tačiau, kaip rodo Hadot tyrinejjimai, šiuolaikinių konsultuojančiu filosofų veikla iš esmès atgaivina filosofijos pirmapradę formą - filosofijos, kurioje filosofinis diskursas atlieka tik pagalbinę funkciją filosofinio gyvenimo būdo pasirinkimo atžvilgiu.

Filosofinis konsultavimas yra tokia filosofavimo forma, kai, užuot apsiribo-

\section{Literatūra}

Blumenberg H. 1979. Schiffbruch mit Zuschauer. Frankfurt a. M.: Suhrkamp.

Blumenberg H. 1987. Die Sorge geht über den Fluß. Frankfurt a. M.: Suhrkamp.

Blumenberg H. 2013. Paradigmen zu einer Metaphorologie. Frankfurt a. M.: Suhrkamp.

Blumenberg H. 2014. Arbeit am Mythos. Frankfurt a.M.: Suhrkamp.

Goethe J. W. 2003. Faustas. Tragedijos antra dalis. Vertè A. Jonynas. Vilnius: Lietuvos rašytojų sąjungos leidykla.

\section{Nuorodos}

1 Čia galima būtų pridurti tokius metaforiškus posakius kaip "sudužo visos mano svajonès“, „paskendau rūpesčiuose" ar „pagaliau pasiekiau ramybès uostą". Antikoje (ypač stoiku filosofijoje) visko netekimas (svajonių, vilčių, turto) buvo traktuojamas kaip iniciacija i filosofija, tiksliau, paskata gyventi filosofini gyvenimo būdą. jus bendro pobūdžio samprotavimais apie tikrovę, stengiamasi padèti konkrečiam žmogui susidoroti su ji kankinančiomis gyvenimiškomis problemomis, reikalauja peržengti iprasto, t. y. abstrakčiomis sąvokomis grindžiamo filosofinio diskurso ribas ir atsigręžti ị metaforini kalbejimo modusa, kuris ne tiek perteikia informacija, kiek atveria egzistencini prasmès matmeni.

Hadot P. 2005. Antikos filosofija. Kas tai? Vertè A. Grigaravičiūtè. Vilnius: Aidai.

Hadot P. 2008. N'oublie pas de vivre. Goethe et la tradition des exercices spirituels. Paris: Albin Michel.

Kerényi K. 2014. Eleusis. Archetypowy obraz matki $i$ córki. Kraków: Homini.

Nietzsche F. 1997: Tragedijos gimimas. Vertè A. Tekorius. Vilnius: Pradai.

Steiner G. 1998. Tikrosios esatys. Vertė L. Jonušys. Vilnius: Aidai.

2 Figu, kaip ir kviečių varpų bei aguonų, įvaizdis yra dažnas ne tik stoikų filosofijoje, bet yra labai reikšmingas Eleusino misterijose (plg. Kerényi 2014).

3 „FAUSTAS: Kas buvo ir kas bus nebesvarbu, Gyvena siela HELENA: Mirksniu nuostabiu“ (Goethe 2003: 228). 